\title{
ALCONPAT Journal
}

WWw.revistaalconpat.org

eISSN 2007-6835

Journal of the Latin-American Association of Quality Control, Pathology and Recovery of Construction

\section{Integrated technical management systems: inspection and repair of non-structural elements}

\author{
G. T. Ferraz ${ }^{1}$, J. de Brito ${ }^{1}$, V. P. De Freitas ${ }^{2}$, J. D. Silvestre ${ }^{1}$
}

${ }^{1}$ IST, Lisbon; Portugal.

${ }^{2}$ FEUP, Porto; Portugal.

\begin{abstract}
Article information
DOI:

http://dx.doi.org/10.21041/ra.

$\underline{v i 2.83}$

Article received on

Febrery 16, 2015, reviewed

under the publishing policies of ALCONPAT Journal and accepted on April 25, 2015. Any discussion, including the replica of the authors, shall be published in the second number of the year 2016 as long as the information is received prior to the closing of the first number of the year 2016.
\end{abstract}

๑) 2015 ALCONPAT Internacional

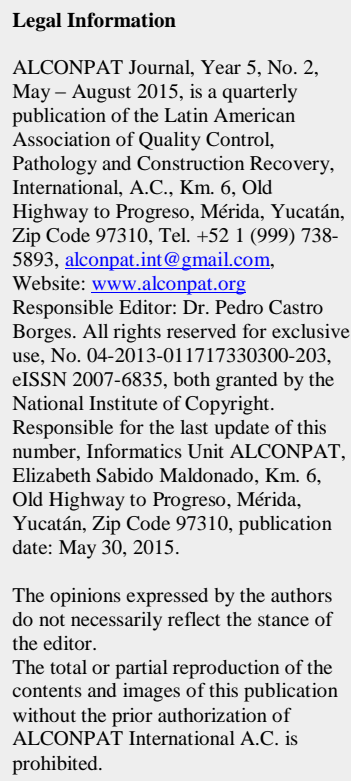

\section{ABSTRACT}

The international scientific community has devoted a great deal of attention to the vast area of knowledge of inspection, diagnosis, maintenance and renovation of buildings, which may be used in the development of integrated building management systems. In this article, we provide a framework for the evaluation methods of the pathology of non-structural elements of buildings, based on current methods, presenting some of the challenges in this area. We present a model to be enforced in the integrated management systems of a building, along with some of the challenges of this area. We also introduce a model to be enforced in the integrated management systems of a building, forming a conductor line and a consistent foundation for a system to be put in place.

Keywords: construction pathology; expert system based on performance; evaluation method; building management.

\section{RESUMO}

A comunidade científica internacional tem dedicado a maior atenção ao vasto campo do conhecimento da inspecção, diagnóstico, manutenção e reabilitação das construções, o qual pode ser utilizado no desenvolvimento de sistemas de gestão integrada de edifícios. Neste artigo, é feito um enquadramento aos métodos de avaliação da patologia em elementos não-estruturais de edifícios, com base nos actualmente existentes, apresentando-se alguns dos desafios neste domínio. É também apresentado um modelo a implementar em sistemas de gestão integrada de um edifício, constituindo uma linha condutora e uma base de trabalho consistente para que um sistema deste tipo seja posto em prática.

Palavras-chave: patologia da construção; sistema pericial baseado no desempenho; método de avaliação; gestão de edifícios.

\section{RESUMEN}

La comunidad científica internacional ha dedicado mucha atención a la vasta área de conocimiento de la inspección, diagnóstico, mantenimiento y rehabilitación de edificios, que se puede utilizar en el desarrollo de sistemas de gestión de edificios integrados. En este artículo, se realiza un encuadramiento de los métodos de evaluación de patología en elementos no estructurales de los edificios, basado en los actuales, presentando algunos de los desafíos en esta área. También se presenta un modelo a implementar en sistemas integrados de gestión de un edificio, formando una línea conductora y una base consistente para un sistema que se ponga en su lugar.

Palabras clave: patología de la construcción; sistema experto basado en el desempeño; método de evaluación; gestión de edificios.

Corresponding author: Jorge de Brito (jorge.brito@civil.ist.utl.pt) 


\section{PRELIMINARY CONSIDERATIONS}

The period of use of buildings is the most important in their useful life from an economic and environmental perspective. The useful life of a building corresponds to the period of time after the construction during which a building or its elements exceed the minimum functional requirements for which it was built (Haapio and Viitaniemi, 2008). Therefore, the consensus today is that the extension of the useful life of buildings, as a consequence of their deterioration, is the most viable option (de Brito, 2009).

At a national level, the absence of policies that encourage restoration and maintenance activities, along with an economic scenario that promoted new construction, favored the suburban growth for decades. In this context, Portugal presents a change of paradigm in the construction sector, which includes a change in focus from new construction to the renovation of existing buildings. In fact, when buildings are subjected to maintenance and rehabilitation, the duration of the construction elements is augmented, increasing the expected useful life of the building (Amaral and Henriques, 2013).

Taking into consideration the uniqueness of each building and the different types of defects, it is possible to identify patterns when analyzing a selection of building samples. The databases that offer information on maintenance and repair, through the systematical analysis of the data collected from inspections, were initiated in this manner. Maintenance and renovation activities are fundamental for the durability of the buildings; it is therefore essential to have an accurate interpretation of their defects, based on objective inspections and diagnoses. However, the inspection and diagnosis procedures of the buildings are very complex, a factor which influences the precision of the underlying intervention measures (Aguiar et al., 2006).

The national and international scientific communities have devoted a great deal of attention to the vast area of knowledge of inspection, diagnosis, maintenance and renovation of buildings, including their use in the development of integrated building management systems. A great deal of effort has been put into the incorporation of computer models in order to help engineers in the decision-making processes (Farinha et al., 2005). Even when the building management systems are tritely used in companies, the main focus of such systems is usually the management of the heritage value and the planned maintenance (Chang and Tsai, 2013). However, the defects in buildings may compromise their performance on a structural and/or non-structural level, occasionally making it necessary to intervene several times at great costs in order to return the building to its original state. Therefore, not using management systems that incorporate the inspection and assessment of buildings could compromise performance in the long term (Amaral and Henriques, 2013).

The construction pathology studies have received much attention presently. In this article, we review the area of evaluation methods of building pathology, presenting some of the challenges in this regard when it comes to the implementation of an integrated building management system that is reliable and applicable.

\section{BUILDING PATHOLOGY EVALUATION METHODS}

Developments regarding the subject of information technologies have favored the automatization of decision-making processes in engineering. At the end of the 1980s, intense activity in the engineering areas led to the implementation of several management systems in regards to the different areas of engineering (Farinha et al. 2005). With respect to the construction pathology, the 
most important building pathology evaluation methods are chronologically presented, focusing on the non-structural elements.

\subsection{DEFECT ACTION SHEETS (1982)}

The British BRE (Building Research Establishment) organization, specialized in buildings, published a series of building defect action sheets comprising a significant database (Trotman, 2006). In short, 144 defect action sheets were published between 1982 and 1990. The aim of these action sheets is to provide the necessary information to the professionals of the construction sector, in aspects of prevention and correction of defects in buildings. Each action sheet is comprised by two A4 sheets structured in the following manner: i) Description of the defect; ii) Description of the causes; iii) Prevention measures; and iv) References and complementary information. Subsequently, these sheets were grouped and re-published (BRE, 2001; CIB - W086 Building Pathology, 2013).

\subsection{DEFECT REPAIR SHEETS (1985)}

In the proceedings of the $1^{\text {st }}$ Meeting on Conservation and Rehabilitation of Residential Buildings, carried out in Lisbon in June 1985, a methodology for the evaluation of building pathology was presented, which would be adopted in the elaboration of the defect repair sheets published by the National Civil Engineering Laboratory (LNEC, 1985). The set of these sheets is segmented in the following manner: i) Structural anomalies; ii) Non-structural anomalies; and iii) Facilities and equipment. A group of defect repair sheets corresponds to each one of the segments. Each sheet was structured in the following manner: i) Symptoms; ii) Examination; iii) Diagnosis of the causes; and iv) Repair.

\subsection{FAILURE CASES, INFORMATION SHEET (1993)}

The International Council for the research and Innovation in Buildings and Construction - CIB (Conseil International du Bâtiment) has a work group focused on the research of construction pathology, named W086 Building Pathology. In June 1993, this work group published a model of pathology sheets entitled Cases of failure information sheet, completely devoted to the pathology records, noting the need for the systematization of knowledge in the field (CIB - W086 Building Pathology, 1993). A structure was suggested for the preparation of pathology sheets: i) Constructive element; ii) Description of the problem; iii) Description of evident defects; iv) Description of the defects that can be monitored; v) Graphical representation (photo, picture); vi) Description of the defect; vii) Identification of the agents that cause the defect; viii) Mistakes; and ix) Diagnosis report

\subsection{FICHES PATHOLOGIE DU BÂTIMENT (1995)}

In 1995, the French agency AQC (Agence Qualité Construction), in partnership with the SMA foundation, developed a set of pathology sheets, entitled Fiches pathologie du bâtiment (AQC, 2014). These sheets were elaborated in order to evidence the main anomalies in French buildings, based on the analyses of incidents reported to the insurance companies. The 61 sheets were created in 1995 and have been available online since 2003 (see figure 1). These were grouped and sectioned according to the parts of the affected building. In a similar fashion to the aforementioned cases, these sheets are structured in the following manner: i) Description of the defect; ii) Diagnosis; iii) Sensitive points; iv) Prevention councils; and v) Additional information. 


\subsection{CONSTRUDOCTOR (2003)}

The Portuguese company OZ - Diagnóstico, Investigación y Control de Calidad de Estructuras y Fundaciones, Lda. developed a service of pre-diagnosis of defects in buildings, called Construdoctor (Ribeiro and Cóias, 2003). The service arises as a system that provides an on-line diagnosis, the main objective of which is to help correct defects in buildings, providing basic explanations of the probable causes, forming a preliminary diagnosis and defining corrective measures. The service offers a pre-diagnosis based on an on-line form (see figure 2). After the submission of the form, the responses of the interviewee are evaluated by specialists in construction pathology and rehabilitation, who fill out an on-line report identifying the defect and specifying the possible causes and corrective actions.
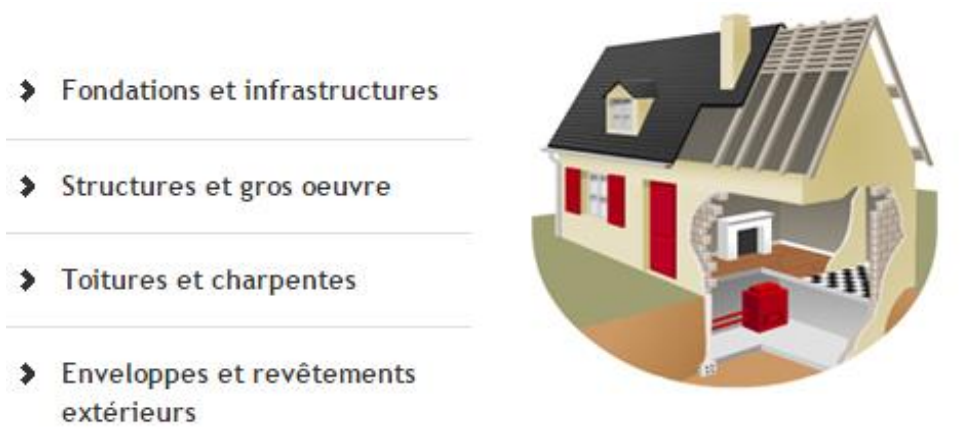

> Équipements

> Aménagements intérieurs

Figure 1. Fiches pathologie du bâtiment (AQC, 2014)

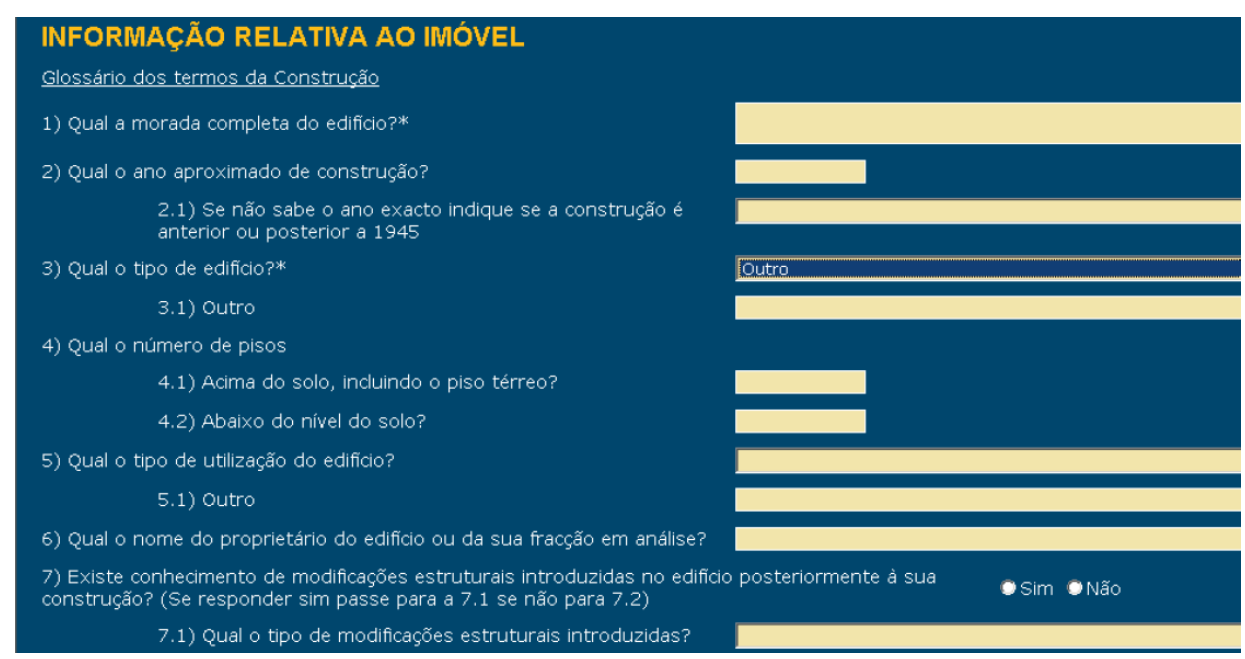

Figure 2. On-line form (Construdoctor) (Ribeiro and Cóias, 2003)

\section{6 "LEARNING FROM MISTAKES" (2004)}

The Italian pathology catalogue "Learning from mistakes" (BEGroup, 2004) was developed by the BEGroup of the Department of Science and Technology of the Constructed Patrimony (BEST) in the Polytechnic University of Milan. The aforementioned catalogue can be accessed on-line in Italian (see figure 3) where the pathology files can be found. Similar to the cases previously mentioned, these sheets are structured in the following manner: i) Material records; ii) Mechanisms of deterioration; iii) Pathology records; iv) Records of case studies; and v) Records of defects. 


\subsection{PATORREB (2004)}

The Group of Studies of Construction Pathology created a website dedicated to the circulation of a catalogue of pathology sheets (Freitas et al., 2007). Since 2004, registered users have access to the area of Pathology, where the layout of a building presents the pathology sheets according to the constructive element (see figure 4). When selecting the corresponding element, the list of associated pathology sheets is presented. Similar to the other cases, these sheets are structured in the following manner: i) Identification of the pathology; ii) Description of the pathology; iii) Surveys and measurements; iv) Causes of the pathology; and v) Possible repair solutions.

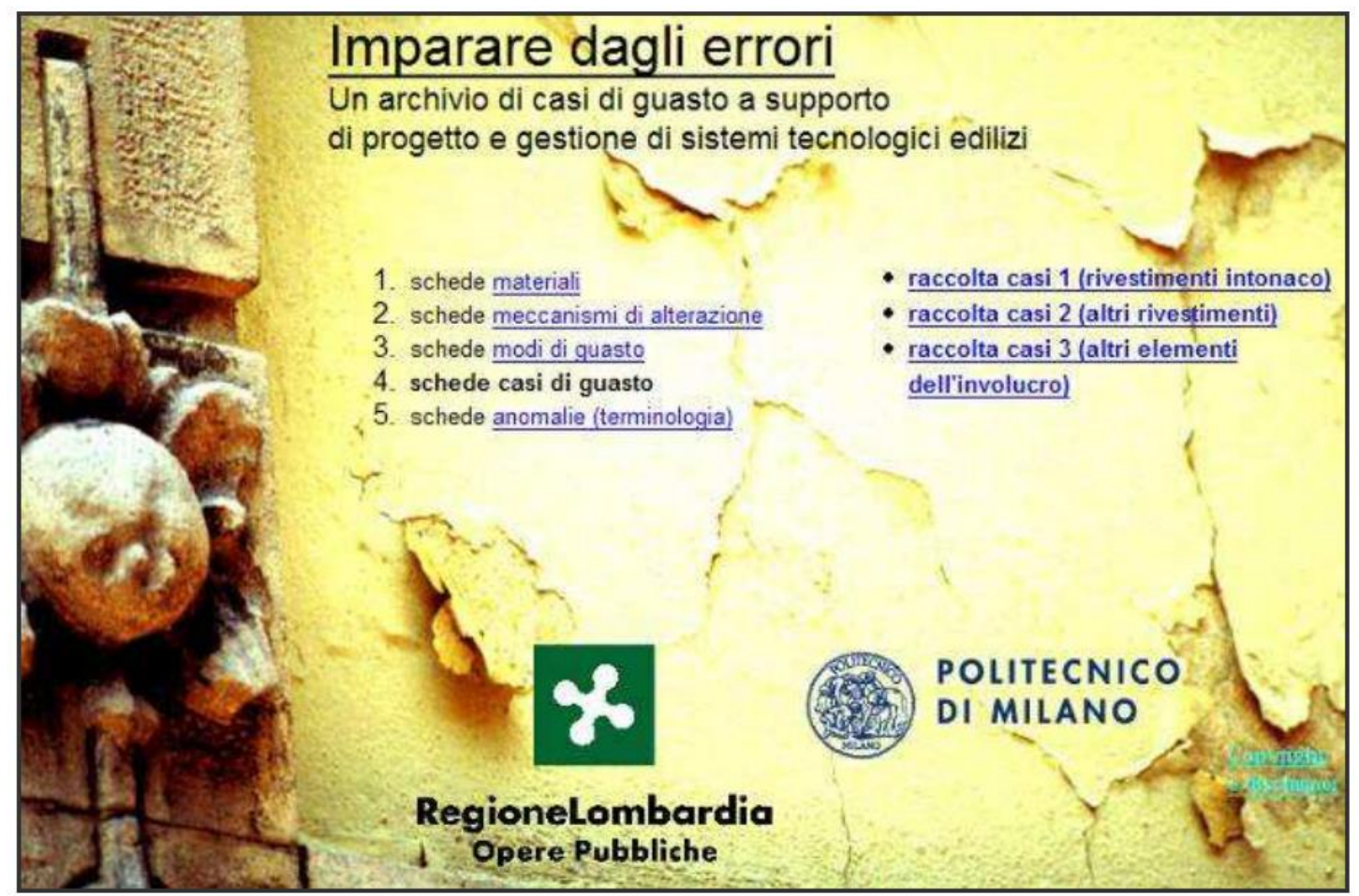

Figure 3. "Learning from mistakes" (BEGroup, 2004)

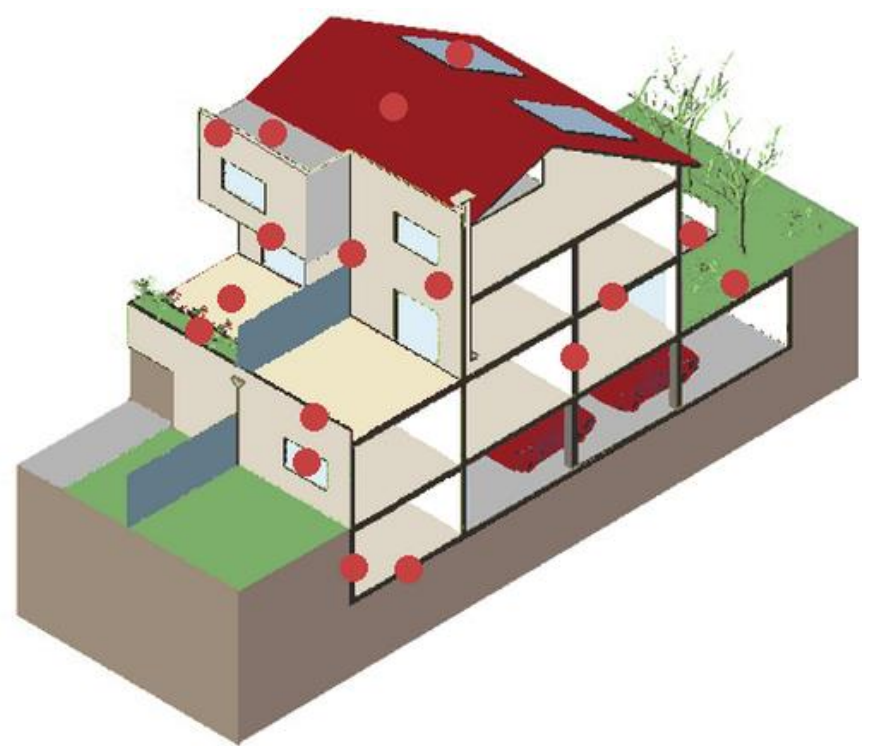

Figure 4. Layout of a building (Patorreb) (Freitas et al., 2007) 


\subsection{WEB-BASED PROTOTYPE SYSTEM (2009)}

In 2009, Fong and Wong created the prototype of an integrated building management system (see figure 5), having several objectives in mind: i) provide a friendly approach to the user; ii) provide a simple approach in the process of information presentation; and iii) allow for the communication between the different users of the system, improving the exchange of knowledge and experience in the scope of construction pathology (Fong and Wong, 2009). With this purpose, a questionnaire was used in order to investigate the opinions of construction professionals as well as the capture and re-use of their knowledge and experience. After the preliminary upload, interviews will be done to interested professionals, and the accumulated knowledge and experience will be recorded in forms free of any structure, which will be subsequently introduced to the prototype of the integrated management system.

\subsection{MAINTENANCE OF THE WEBSITE (2010)}

In 2004 at the National University of Singapore (NUS), a two-year project was developed; it was conceived in order to study the problems that affected different types of buildings in tropical weather. In 2005, the Maintainability website was created (see figure 6), which was updated until 2010. The website seeks to create awareness among the construction professionals in regards to the obstacles for the good maintenance of a building (Chew, 2010). This website was developed in English and is divided into the following modules: i) Library of defects/anomalies, with information on the types of defects and their causes, maintenance and diagnosis method; ii) Manual of materials, with information about the development and durability of the materials; and iii) Evaluation system of the maintenance, developed in order to facilitate the selection of sustainable alternatives. The module i) Library of defects, is directly related to the scope of this article, based on the information of defects and is grouped in the following manner: i) Defects on facades, ii) Defects in humid areas, iii) Defects on warehouses; and iv) Defects on roofs. In regards to the records of defects, these are organized in the following manner: in the first two sections, the type of defect is illustrated and the possible causes are explained; the good constructive practices are compiled in the third section in order to avoid systematic mistakes; in the fourth section the techniques of diagnosis and maintenance are illustrated; the possible corrective techniques are illustrated in the fifth section.

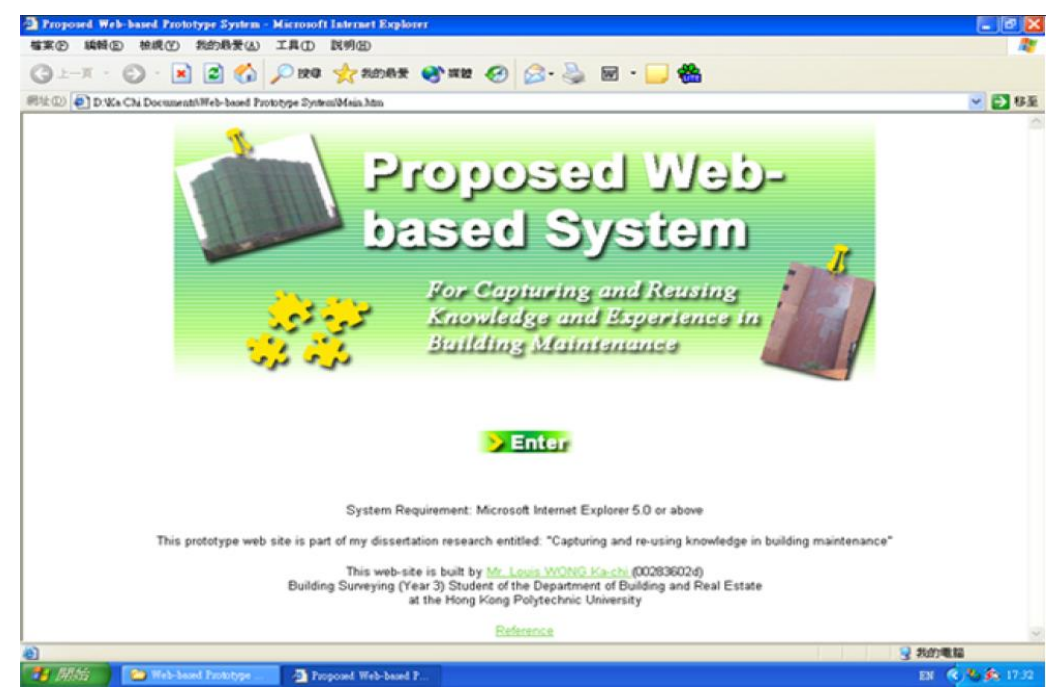

Figure 5. Web-based prototype system (Fong and Wong, 2009) 


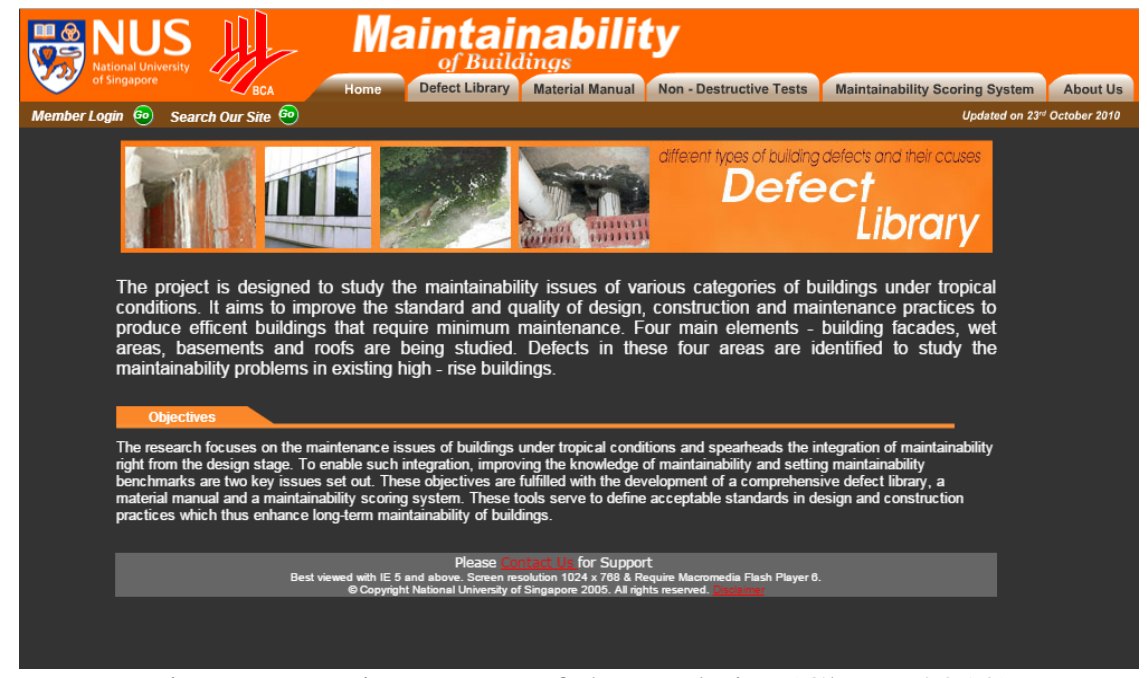

Figure 6. Maintenance of the Website (Chew, 2010)

\subsection{BUILDING A MEDICAL RECORD (2013)}

In 2013, Chang and Tsai proposed the concept of "building medical records", similar to human medical records (Chang and Tsai, 2013), presenting a diagnosis system. In the application of this system, an expert on the research of pathological situations with a database can be assisted for the diagnosis of defects in buildings. The user receives the notification through an Internet connection on the site of the construction. This system is comprised of four main modules: i) Processing of documents; ii) Extraction of the key solution; iii) Calculation of the simulation; and iv) Classification of the importance. According to the authors, construction companies may offer specialized services in response to the maintenance and management problems using this system. The efficient accumulation and reuse of repair records may also be done during the project phase of a building.

\section{CRITICAL AND COMPARATIVE ANALYSIS}

Even though in building rehabilitation each case is unique, the majority of defect occurrences in non-structural elements can be resolved in a systemic manner. Using data from inspections or from the crossing of information and an integrated building management system, an inspector may diagnose the defect and define the best repair technique. In this context, the acquisition of data on the development of defects in construction is of vital importance for the planning of maintenance and repair actions. The reliability of this information is fundamental in making rational decisions. From the analysis of the evaluation methods of building pathology, we can easily conclude that they all have a similar structure when it comes to the description of defects: i) description / identification of the defect; ii) probable causes; and iii) Diagnosis and repair technique. Undoubtedly, it seems that all pathology evaluation methods for the buildings found in literature have a similar organization, but none of them is completely dedicated to intervention, which enforces the importance of research in regards to this topic.

In relation to the evaluation methods based on defect sheets, Defect action sheets (1982), Repair defect sheets (1985) and Cases of failure information sheet (1993), these represent the starting point for the systemic analysis of building pathology. Through the systematic analysis of the collected data in research studies, it was possible to establish reliable databases, which provide some orientation in the prevention and repair of defects of non-structural elements of buildings; it is an important contribution in the development of integrated management. In this sense, the content of 
the information could be in disagreement with the common constructive practices, due to the continuous advancements in the construction and repair techniques.

In regards to those evaluation methods that make use of the most recent information technologies, it is possible to identify three similar methods in their creation: Fiches pathologie du bâtiment (1995), "Learning from mistakes" (2004) and Patorreb (2004). In these cases, several defect sheets are accessible through a website from which they can be downloaded and printed. Through these methods, the divulgation of the pathology records became a reality. However, no measures were taken in order to filter the content of the pathology sheets in order to offer the users an expedited repair solution.

The Construdoctor (2003) and Building medical record (2013) evaluation methods emerged as systems that offered an on-line diagnosis. After completing the form, the user's responses are evaluated by construction pathology specialists who create an on-line report. It can also be observed that the information offered in the report is just a pre-diagnosis offered by technicians, without previously having had a view of the building. For this reason, the report cannot be as accurate as desired.

In regards to the Web-based prototype system (2009) method, it is important to note that the system was not conceived to offer any systematized rule. According to the authors, the investigations concluded that the knowledge in regards to construction pathology is obtained from a specific context and cannot be generalized. Instead, the system allows the users to share and recover the experience of other professionals in order to facilitate their own decision-making process.

Finally, it is important to give greater attention to the Maintainability website (2010) method. This method can provide an objective diagnosis through the development of a library of defects, including a manual of materials and a classification system for the maintenance techniques. In regards to the library, the defects and their corresponding causes are explained and illustrated through photographs. The diagnosis and repair techniques are also included. In this manner, the users of this evaluation method are encouraged to find a diagnosis based on images. However, statistical information was not found, specifically when it comes to correlations between defects, diagnoses and repair techniques. As a result, the diagnosis may not be as accurate as expected, as it is clearly dependent on the experience of the user / inspector. Due to this, the method presents some challenges regarding intervention.

Among other identified challenges on the evaluation methods of building pathology found in literature, the objectivity of the information given is a pre-requisite for the making of rational decisions. In order to overcome some of the challenges found, researchers from the Instituto Superior Técnico of the Universidad de Lisboa developed inspection and diagnosis systems, applied to several non-structural constructive elements. These systems are characterized by the definition and classification of the four most important variables in the pathology: defects, causes, diagnosis techniques and repair techniques, as they also established quantitative correlations (de Brito, 2009). Following a systemic approach, studies were published about the following nonstructural elements in buildings:

i) Waterproofing of roofs (Walter et al., 2005);

ii) Ceramic coverings for floors and walls (Silvestre and de Brito, 2009; Silvestre and de Brito, 2010; Silvestre and de Brito, 2011);

iii) Epoxy coatings for industrial floors (Garcia and de Brito, 2008);

iv) Slab walls (Gonçalves et al., 2013, 2014);

v) Coatings for wood floors (Delgado et al., 2013);

vi) Natural stone claddings for floors and walls (Neto and de Brito, 2011; Neto and de Brito, 2012)

vii) Divisions made of laminated plaster (Gaião et al., 2011; Gaião et al., 2012); 
viii) Common friezes on internal facades (Palha et al., 2012; Pereira et al., 2011);

ix) Coatings on inclined roofs (Garcez et al., 2012; Garcez et al., 2015a; Garcez et al., 2015b);

x) Plaster on walls (Sá et al., 2015a; Sá et al., 2015b);

xi) Frieze paint (Pires et al., 2015a; Pires et al., 2015b);

xii) ETICS (Amaro et al., 2013; Amaro et al., 2014);

xiii) M (Santos, 2012; Vicente, 2012).

Through an intense literature research based on scientific international publications, current available information on the pathology of non-structural elements was collected. This information was complemented with the execution of field work with extensive representative samples, allowing for the creation of a better understanding in relation to the origin of the defects, offering a systemic method for the diagnosis and facilitating the election of intervention methods for repair. These systems have the following tools:

i) List of classifications of defects: identification and classification of the more common defects in each element;

ii) Clarifying list of causes: identification and classification of the most probable causes of different identified defects;

iii) Classification list of diagnosis techniques: classification of the type of test that allows for the characterization of the identified defects, as well as helping in the determination of the possible cause;

iv) Classification list of repair techniques: classification of the type of intervention technique that is more adequate for each one of the defects identified;

v) Correlation matrix of defects-causes: attribution of null relation, indirect or direct between each defect and each cause listed;

vi) Correlation matrix of inter-defects: probability of the development of a defect, in the presence of another;

vii) Correlation matrix of defects-diagnosis techniques: attribution of a null, average or high relation to a diagnosis technique necessary for the characterization of a defect, or the understanding of their conditions in order to obtain some knowledge of the origin;

viii) Correlation matrix of defect-repair techniques: attribution of a null, average or high relation to a relative repair technique to its adequacy in the resolution of defects.

In the meantime, none of the systems created are dully computerized, making them still vulnerable to inaccurate interpretations and for errors in their use.

\section{FUTURE PERSPECTIVES}

In the area of building rehabilitation, it is established that the rehabilitation procedure shall start with an inspection, ensuring the correct characterization of the existing defects, which will finish with the presentation of a diagnosis and the corresponding repair technique. Having verified the importance of establishing evaluation methods for the building pathology, it is important to create a trustworthy integrated building management system, which will facilitate access to the wide field of construction pathology.

Starting with the analysis of the evaluation methods of building pathology found in literature, it has been concluded that all have a similar organization but that none of them is entirely dedicated to intervention. In order to create a trustworthy integrated management system, the partial systems developed in the Instituto Superior Técnico of the Universidad de Lisboa are featured as reliable sources, once they operate by the same systematical approach, anchored in the knowledge of the areas of inspection, diagnosis and rehabilitation of non-structural elements in buildings. Through 
this systemic approach, the most important parameters of the pathology of several elements of construction were defined and classified, as well as the quantitative correlations between them. In this context, the creation of a global integrated management system, including all developed partial systems up to date, arises as a future and credible perspective.

The implementation of an integrated building management system supported by the partial systems developed in the Instituto Superior Técnico will put in to practice all the tools mentioned in section 3 of this article. However, there is a long road ahead in order to implement this system. The creation of a global system based on normalized lists of defects, causes, inspection methods and repair techniques represent a great challenge due to the large amount of information. The analysis and normalization of the partial systems include the joint appreciation of defects, causes, diagnosis techniques and repair methods of each constructive element.

In order to implement an integrated building management system, the different stages through which a building goes shall be considered, including the general and specific periodic inspections for the elements that comprise the building, be it the subsequent maintenance interventions, repairs and/or substitutions. In order for a system of this kind to be implemented, it is necessary to build a computerized tool that is based on the building and its elements. This system shall include a database that allows for the storage of relevant information about the building; a module that allows for the normalization of the inspection activities and the resulting reports; it is a decision module about the action to be taken after the inspection and the diagnosis of eventually existing defects, dedicated to the maintenance operations of the building. Using the aforementioned attributes, a decrease in subjectivity of building elements inspections is expected, as well as the elimination of the dependence on the inspector's experience, that represent some of the challenges associated to the evaluation methods for the pathology of existing buildings.

Finally, it has been expected that the proposed computerized inspection system has the following practical application: i) use in inspections; ii) use in the area of proactive maintenance plans for buildings; iii) support in the decision of rehabilitation projects; iv) preparation of reports on the dilapidation of buildings; v) use for official acknowledgement; vi) preparation of the final report on the diagnosis with a normalized structure; vii) use as a pre-normative base of normalized methodology for inspections to buildings that must be officially acknowledged; and viii) evaluation and management of property assets.

\section{REFERENCES}

Aguiar, J., Paiva, J. e Pinho, A. (2006), "Guião de apoio à reabilitação de edifícios habitacionais", LNEC, Lisboa.

Amaral, S. e Henriques, D. (2013), "Inspection and diagnosis: A contribution to modern buildings sustainability." Proc., Portugal SB13, Guimarães, Portugal, Multicomp, pp. 75-82.

Amaro, B., Saraiva, D., de Brito, J. e Flores-Colen, I. (2013), "Inspection and diagnosis system of ETICS on walls." Construction and Building Materials, Volume 47, pp. 1257-1267.

Amaro, B., Saraiva, D., de Brito, J. e Flores-Colen, I. (2014), "Statistical survey of the pathology, diagnosis and rehabilitation of ETICS in walls." Journal of Civil Engineering and Management, Volume 20, pp. 511-526.

AQC (2014), Agence Qualité Construction. [Online] Disponível em: http://www.qualiteconstruction.com/outils/fiches-pathologie.html

BEGroup (2004), Imparare dagli errori, Italy, Regione Lombardia (em Italiano).

BRE (2001), Defect Action Sheets - The complete set, London, BREPress. 
Chang, C.-Y. e Tsai, M.-D. (2013), "Knowledge-based navigation system for building health diagnosis." Advanced Engineering Informatics, Volume 27, pp. 246-260.

Chew, Y. L. (2010), Maintainability of facilities: for building professionals. Singapore, World Scientific.

CIB - W086 Building Pathology (1993), Building pathology: A state-of-the-art report, Delft, Netherlands: CIB.

CIB - W086 Building pathology (2013), A state-of-the-art report on building pathology, CIB, FEUP, LFC.

de Brito, J. (2009), "Sistemas de inspecção e diagnóstico em edifícios." Porto, Portugal, $3^{\circ}$ Encontro sobre Patologia e Reabilitação, pp. 13-23.

Delgado, A., de Brito, J. e Silvestre, J. D. (2013), "Inspection and diagnosis system for wood flooring." Journal of Performance of Constructed Facilities, Volume 27, pp. 564-574.

Farinha, F., Portela, E., Domingues, C. e Sousa, L. (2005), "Knowledge-based systems in civil engineering: Three case studies." Advances in Engineering Software, Volume 36, p. 729-739.

Fong, P. S. W. e Wong, K. (2009), "Knowledge and experience sharing in project-based building maintenance community of practice." International Journal of Knowledge Management Studies, Volume 3, pp. 275-294.

Freitas, V. P. d., Alves, S. e Sousa, M. (2007), "Um contributo para a sistematização do conhecimento da patologia da construção em Portugal - www.patorreb.com". Proc., $2^{\circ}$ Congresso de Argamassas de Construção, Lisboa, Portugal.

Gaião, C., de Brito, J. e Silvestre, J. (2011), "Inspection and diagnosis of gypsum plasterboard walls." Journal of Performance of Constructed Facilities, Volume 25, pp. 172-180.

Gaião, C., de Brito, J., Silvestre, J. (2012), "Technical Note: Gypsum plasterboard walls: inspection, pathological characterization and statistical survey using an expert system." Materiales de Construcción, Instituto Eduardo Torroja, Spain, pp. 285-297.

Garcez, N., Lopes, N., de Brito, J. d. e Sá, G. (2012), "Pathology, diagnosis and repair of pitched roofs with ceramic tiles: Statistical characterisation and lessons learned from inspections." Construction and Building Materials, Volume 36, pp. 807-819.

Garcez, N., Lopes, N., de Brito, J. e Silvestre, J. (2015a), "System of inspection, diagnosis and repair of external claddings of pitched roofs." Construction and Building Materials, Volume 35, pp. 1034-1044.

Garcez, N., Lopes, N., de Brito, J., Sá, G., Silvestre, J. (2015b), "Influence of design on the service life of pitched roofs' cladding.", Journal of Performance of Constructed Facilities, Volume 29, No. 3, pp. 04014073.

Garcia, J. e de Brito, J. (2008), "Inspection and diagnosis of epoxy resin industrial loor coatings." Journal of Materials in Civil Engineering, Volume 20, pp. 128-136.

Gonçalves, A., de Brito, J., Branco, F., e Amaro, B. (2013), "Sistema de inspecção, diagnóstico e reparação de paredes de alvenaria." Revista Construlink, vol. 11.

Gonçalves, A., de Brito, J. e Amaro, B. (2014), "Systematic approach to inspect, diagnose, and repair masonry walls." Journal of Performance of Constructed Facilities, doi.org/10.1061/(ASCE)CF.19435509.0000650.

Haapio, A. e Viitaniemi, P. (2008), Service life of a building in environmental assessment of buildings. Istanbul, Turkey, pp. 11-14.

LNEC (1985). Construction pathology (in Portuguese). Lisbon, LNEC, pp. 1-95.

Neto, N. e de Brito, J. (2011), "Inspection and defect diagnosis system for natural stone ciadding." Journal of Materiais in Civil Engineering, Volume 30, pp. 1433-1443.

Neto, N. e de Brito, J. (2012), "Validation of an inspection and diagnosis system for anomalies in natural stone cladding." Construction and Building Materials, Volume 30, pp. 224-236.

Integrated technical management systems: inspection and repair of non-structural elements 
Palha, F., Pereira, A., de Brito, J. e Silvestre, J. (2012), "Effect of water on the degradation of gypsum plaster coatings: inspection, diagnosis and repair." Journal of Performance of Constructed Facilities, Volume 26, pp. 424-432.

Pereira, A., Palha, F., de Brito, J. e Silvestre, J. (2011), "Inspection and diagnosis system for gypsum plasters in partition walls and ceilings." Construction and Building Materiais, Volume 25, pp. 2146-2156.

Pires, R., de Brito, J. e Amaro, B. (2015a), "Inspection, diagnosis and rehabilitation of painted rendered façades." Journal of Performance of Constructed Facilities, Volume 29, No. 2, pp. 04014062.

Pires, R., de Brito, J. and Amaro, B. (2015b), "Statistical survey of the inspection, diagnosis and repair of painted rendered façades." Structure and Infrastructure Engineering, Volume 11, No. 5, pp. 605-618.

Ribeiro, T. and Cóias, V. (2003), “Construdoctor. Um serviço de pré- diagnóstico via internet.” Proc.

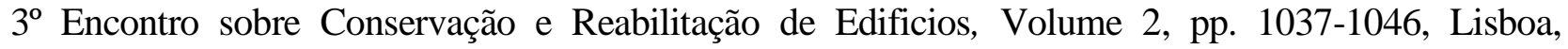
Portugal.

Sá, G., Sá, J. and de Brito, J. (2015a), "Inspection and diagnosis system for rendered walls." International Journal of Civil Engineering, Volume 12, No. 2, pp. 279-290.

Sá, G., Sá, J., de Brito, J. and Amaro, B. (2015b), "Statistical survey on inspection, diagnosis and repair of wall renderings." Journal of Civil Engineering and Management, Volume 21, No. 5, pp. 623636.

Santos, A. (2012), Sistema de inspecção e diagnóstico de caixilharias, Lisboa, Portugal: Dissertação de Mestrado em Engenharia Civil no Instituto Superior Técnico, Universidade de Lisboa.

Silvestre, J. and de Brito, J. (2009), "Ceramic tiling inspection system." Construction and Building Materiais, Volume 23, pp. 653-668.

Silvestre, J. and de Brito, J. (2010), "Inspection and repair of ceramic tiling within a building management system." Journal of Materials in Civil Engineering, Volume 22, pp. 39-48.

Silvestre, J. and de Brito, J. (2011), "Ceramic tiling in building façades: Inspection and pathological characterization using an expert system." Construction and Building Materials, Volume 25, p. 1560-1571.

Trotman, P. (2006), Building pathology at the Building Research Establishment, UK - Cases studies, data bases and feedbacack to the construction industry. $2^{\circ}$ Encontro sobre Patologia $e$ Reabilitação, Porto, Portugal: Edições FEUP, 35 p.

Vicente, M. (2012), Tecnologia e reabilitação de caixilharias, Lisboa, Portugal: Dissertação de Mestrado em Engenharia Civil no Instituto Superior Técnico, Universidade de Lisboa.

Walter, A., de Brito, J. and Lopes, J. G. (2005), "Current flat roof bituminous membranes waterproofing systems - Inspection, diagnosis and pathology classification." Construction and Building Materials, Volume 19, p. 233-242. 